\title{
Temporal influence on foraging strategies, territoriality and nomadic tendencies of Snail Kite, Rosthramus sociabilis (Viellot, 1817) in an urban Neotropical wetland
}

\author{
Posso, SR. *, Cintra, FB. and Frias, J. \\ Laboratório de Ecologia, Sistemática e Conservação de Aves Neotropicais, Departamento de Ciências Naturais, \\ Universidade Federal de Mato Grosso do Sul - UFMS, Av. Ranulpho Marques Leal, 3484, \\ CP 210, CEP 79620-080, Três Lagoas, MS, Brazil \\ *e-mail: srposso@ hotmail.com \\ Received February 02, 2011 - Accepted April, 04, 2011 - Distributed May 31, 2012
}

(With 3 figures)

\begin{abstract}
The foraging, territoriality and displacement of the Snail Kite were studied over 232 hours of observations in an urban lake during the dry and wet seasons. The temperature and rainfall variations were used to correlate with predation rates and the correlation coefficients were 0,39 and 0,34, respectively. Snail Kites spent more time foraging during the wet than the dry season when perching is more frequently recorded. The higher predation in the wet season can be explained by the higher abundance of apple snails and the energy demand for reproduction. In the wet season, the territories were smaller and the conspecific conflicts decreased as prey were more available. However, due to the lack of food in the dry season, intra-specific conflicts and expansion of male territories were observed and the female and immatures were expelled from their foraging area to another location. In this way, site tenacity of Snail Kites should be interpreted in relation to the variations on food and dominance gradients according to the temporal changes (time) and foraging sites (space).
\end{abstract}

Keywords: feeding, territoriality displacement, freshwater raptors, Brazil.

\section{Temporalidade e estratégias de forrageamento, territorialidade e deslocamento do gavião-caramujeiro Rosthramus sociabilis (Viellot, 1817) em uma área urbana úmida Neotropical}

\begin{abstract}
Resumo
Foram estudados os comportamentos territoriais e de forrageio do gavião-caramujeiro em uma lagoa urbana durante as estações seca e chuvosa. Observaram-se esses comportamentos durante 232 horas, sendo a amostragem divida em períodos matutino e vespertino. A maior atividade de forrageio foi observada durante o período matutino. Os principais itens predados foram espécimes do gênero Pomacea spp. No entanto, durante o período de seca, os gaviões-caramujeiros também predaram caranguejos. Essas aves exibiram diferentes estratégias de forrageamento e territorialidade durante as diferentes estações. Os gaviões-caramujeiros dispenderam maior tempo de forrageamento durante a estação chuvosa e maior tempo pousados, durante a estação seca. A expansão/contração dos territórios realizados pelos machos é dependente da disponibilidade de alimento, que varia durante as estações: a) estação seca (pouco alimento): conflitos agonísticos intraespecíficos, seguidos de expansão dos territórios; b) estação chuvosa: conflitos agonísticos decresceram à medida que a oferta de alimento aumentou e, consequentemente, houve redução do tamanho dos territórios. Desse modo, conclui-se que os padrões de movimentação para forragear e estabelecer territórios são altamente dependentes da distribuição de recursos no espaço e no tempo, e estão também associados ao comportamento social, por meio de dominância dos machos.
\end{abstract}

Palavras-chave: forrageio, comportamento territorial, gavião-caramujeiro, Brasil. 


\section{Introduction}

The Neotropical wetlands are an ideal system to study birds because species in distinct regions are exposed to similar variations in resource availability, as a result of marked wet and dry periods and resulting flood pulses (Junk and Silva 1999). Although they are one of the richest habitats for birds, the Neotropical wetlands have been poorly studied, mainly in areas under human influence (Alves and Pereira 1998; Moreno et al., 2004; Pimenta et al., 2007; Silva and Blamires, 2007). It is also remarkable in studies focused on freshwater bird raptors and the variation in predator densities, together with the distribution of prey availability, and their influence on territoriality and stay/leave decisions. In fact, the approaches have been focused mainly in non-urban areas such as in Bourne (1985), Stillman et al. (1996, 1997) and Tyrrell and Hornbach (1998).

The Snail Kite, Rosthramus sociabilis, belongs to the Accipitridae family, within Falconiformes. It is widely distributed from Florida (USA) to Uruguay and Argentina. It exhibits conspicuous sexual dimorphism, measures about $41 \mathrm{~cm}$ in total length and it shows a deeply hooked beak, an adaptation to feed mainly on snails. The Snail Kite lives on wetlands and nests in colonies, sometimes installed on bushes, where male displays can be observed in the breeding season (Sick, 1997).

Two foraging strategies are described for this freshwater raptor: a) "Still-Hutting", the Snail Kite is perched and captures prey by short flies after located them from the perch; b) "Course-Hutting", it flies over in the open water searching for prey (Snyder and Snyder 1969; Beissinger 1983). After finding and capturing prey, it returns to the perch to consume the soft parts, discarding the empty shells on the ground (Sick, 1997).

The Snail Kite is a specialised predator that feeds almost exclusively on apple snails of Pomacea genus (Ampulariidae) (Donnay and Beissinger, 1993). However, it can feed on different food items, either during the wet season, when there is more diversity of resources (Mader, 1981) but mainly in periods of extreme low snail availability (Sykes and Kale II, 1974). Most probably the Snail Kite turns to alternatives of prey when apple snails become scarce, such as during dry periods, but further studies are still needed (Davis et al., 1994).

Although the importance of habitat structure and prey density on temporality is recognised in Snail Kites, the seasonal influence on foraging strategies, territoriality and stay/leave decisions has been overlooked. In fact, studies on Snail Kites have been carried out just on interactions among predation, habitat components and prey-size selection (Haverschmidt, 1970; Sykes and Kale II, 1974; Collet, 1977; Snyder and Kale II 1983; Beissinger 1983; Magalhães 1990; Bourne 1993; Díaz and Blanco, 1996; Estela and Naranjo 2005; Tanaka et al., 2006). This species, locally common and conspicuous freshwater raptor, is an excellent organism for studying such biological aspects.
They are easily detected while foraging and establishing territories (Bourne, 1985).

In this way, we studied the foraging behaviour, territoriality and nomadic tendencies of the Snail Kite associated with foraging sites during a temporal cycle in an urban Neotropical wetland.

\section{Material and Methods}

\subsection{Area of study}

The study was performed in the largest open water, called Lagoa Maior, in the Três Lagoas municipality, Mato Grosso do Sul, Brazil. The local climate is $\mathrm{Cw}$ (Köppen system), with rainfall ranging from $750 / 2000 \mathrm{~mm}$ per year on average, with the occurrence of two seasons as defined dry (May-September) and wet (October-April) (Piratelli et al., 2000).

This open water is located in an urban area $\left(20^{\circ} 46^{\prime} 57^{\prime \prime} \mathrm{S}\right.$ and $\left.51^{\circ} 43^{\prime} 06^{\prime \prime} \mathrm{W}\right)$. Its surroundings are a very busy area with dense residential neighbourhoods, shops, hotels and restaurants and also are widely exploited for recreational purposes. This lake has a circumference of about 2.500 metres and its depth is from $65 \mathrm{~cm}$ to 3 metres. The $\mathrm{pH}$ is slightly alkaline and the water shows maximum turbidity degree of $70 \mathrm{~cm}$ (Secchi) (Leipnitz et al., 2005). The surrounding vegetation includes manly Jacaranda mimosaefolia D. Don, Bombax ceiba L., Inga sp., Roystonea oleracea Jacq, Albizia hassleri, Mangifera indica L., Tabebuia sp. and exotic grasslands. It also has an island composed predominantly of Typha domingensis Pers., Juncus effusus L. and Cecropia pachystachya Trec.

\subsection{Methodology}

The study was conducted from March 2008 to February 2009, covering the wet (October to April) and dry seasons (May to September). The Snail Kite activities were monitored by continuous periods of time, two days per month, subdivided into: 1 ) morning (6 AM to $12 \mathrm{PM}$ ) and; 2) evening (13 to $18 \mathrm{PM})$. We recorded any territorial and foraging behaviours exhibited during the sampling period from all individuals recorded in the study area. The periods involved in each activity were recorded by chronometers.

In a previous study (February, 2008), we recognised four different foraging sites and individual territories. Thus, we divided the sampling in four areas. Data from each area were sampled in order to cover all the lake area and its surroundings (Table 1). According to Snyder and Snyder (1969) we considered the Snail Kites foraging primarily by flying low over the marsh to locate snails in order to check out whether the bird was actually foraging. The territorial behaviour was considered when an individual exhibited vocalisations at approaching conspecifics and ensuing chases if the intruding Snail Kite entered the foraging territory.

We adopted the transect method because it minimises the individual overestimation (Bibby et al., 2000). The studied area comprised the open water and its surroundings (about 30 meters), as proposed by Esteves (1998). 
The monthly average values of temperature and total precipitation were used to correlate with preys capture. These correlations were applied to infer hypotheses about foraging behaviour and territoriality in relation to the temporality. The Pearson correlation coefficient was performed to these parameters.

\section{Results}

We performed about 232 hours of observations on four individuals recorded in the study area: two males, one female and one immature. From the 289 captures recorded, $98.26 \%(\mathrm{n}=284)$ were Pomacea $\mathrm{sp}$. and only $1.74 \%(\mathrm{n}=5)$ were crabs captured in the dry season.

Considering all individuals and periods, the Snail Kites spent approximately 104 hours (45\%) on feeding, 18 hours in flight (8\%), 89 hours perched $(38 \%)$ and 20 hours (9\%) out of the studied area. Figure 1 shows the activities according to the temporal period and Figures 2 and 3, the predation rates according to rainfall and temperature, respectively. The Pearson correlation coefficients for rainfall and temperature to predation rates were 0,39 and 0,34 , respectively.

From the 289 captures, $206(71.3 \%)$ were recorded in the wet season and only $83(28.7 \%)$ in the dry season. The predation rates related to the four areas previously chosen, daily periods and wet and dry seasons, are shown in Table 1.

During the wet season, the males occupied areas with the highest prey availability and landing areas (quadrants III and IV: Table 1), showing male dominance of territories. The males exhibited territorial behaviour including vocalisations at approaching conspecifics and ensuing chases if the intruding snail kite entered the foraging territory. During the dry season, females and the young were dispersed from their breeding area (quadrants I and II) by males and both females and young were not observed in the lake anymore. Moreover, the dominance

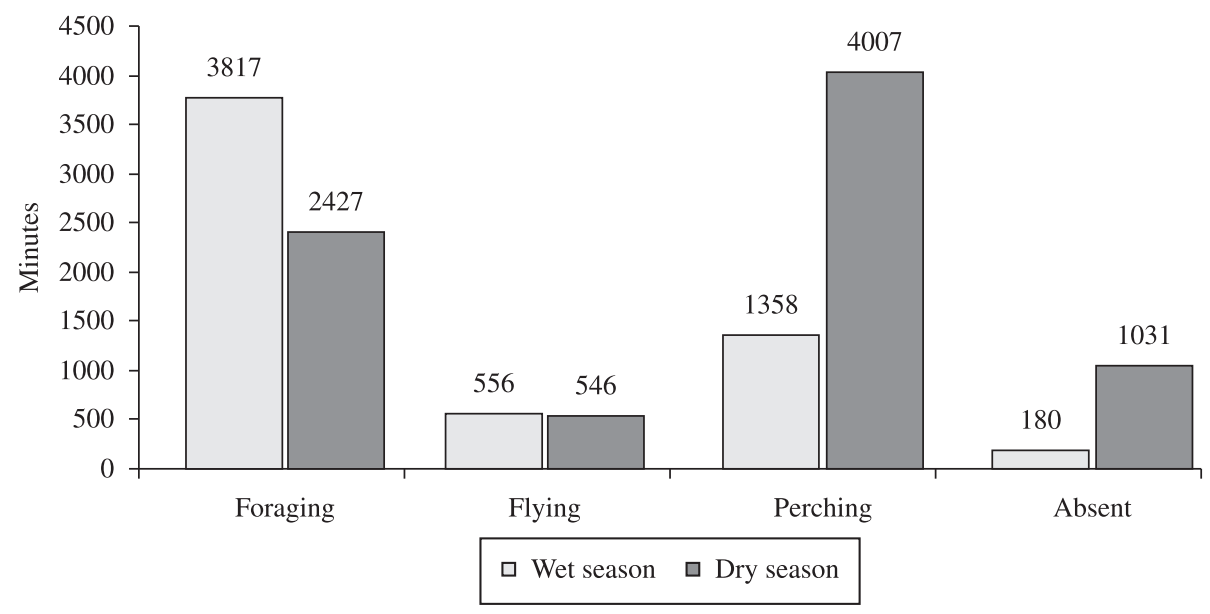

Figure 1. Distribution of Snail Kite activities (in minutes) during the wet and dry seasons in the Lagoa Maior, Três Lagoas, MS.

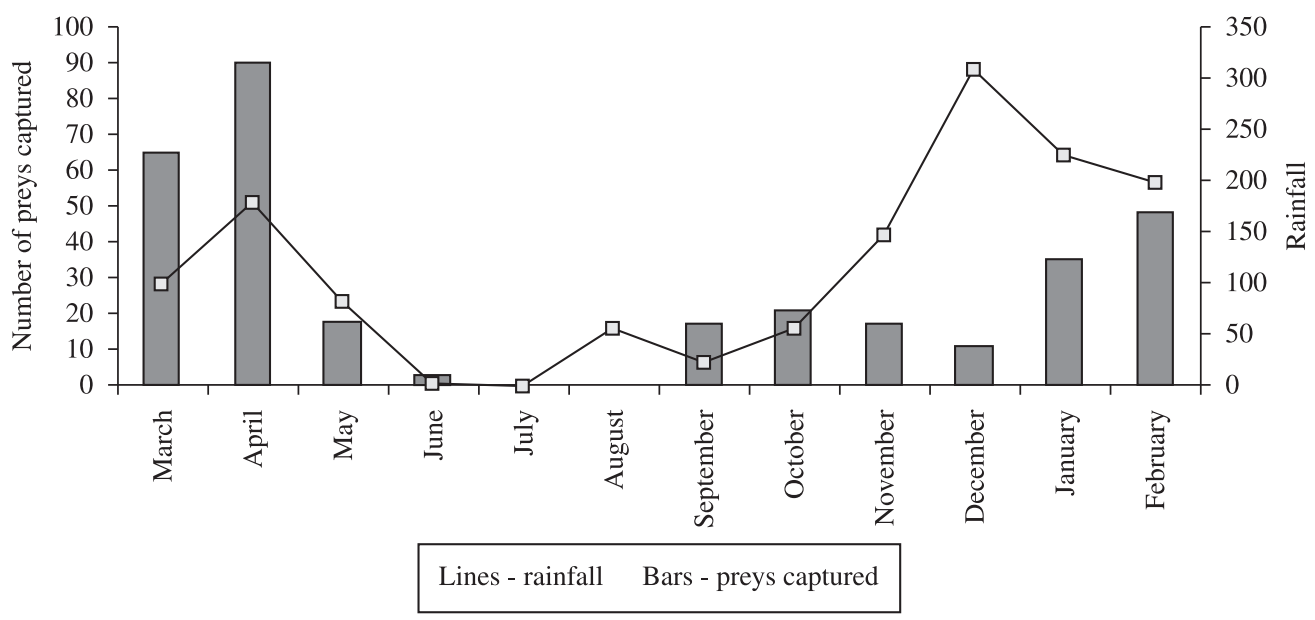

Figure 2. Snail Kite predation rates during the wet and dry season and related to rainfall from March/08 to February/09 in the Lagoa Maior, Três Lagoas, MS. 


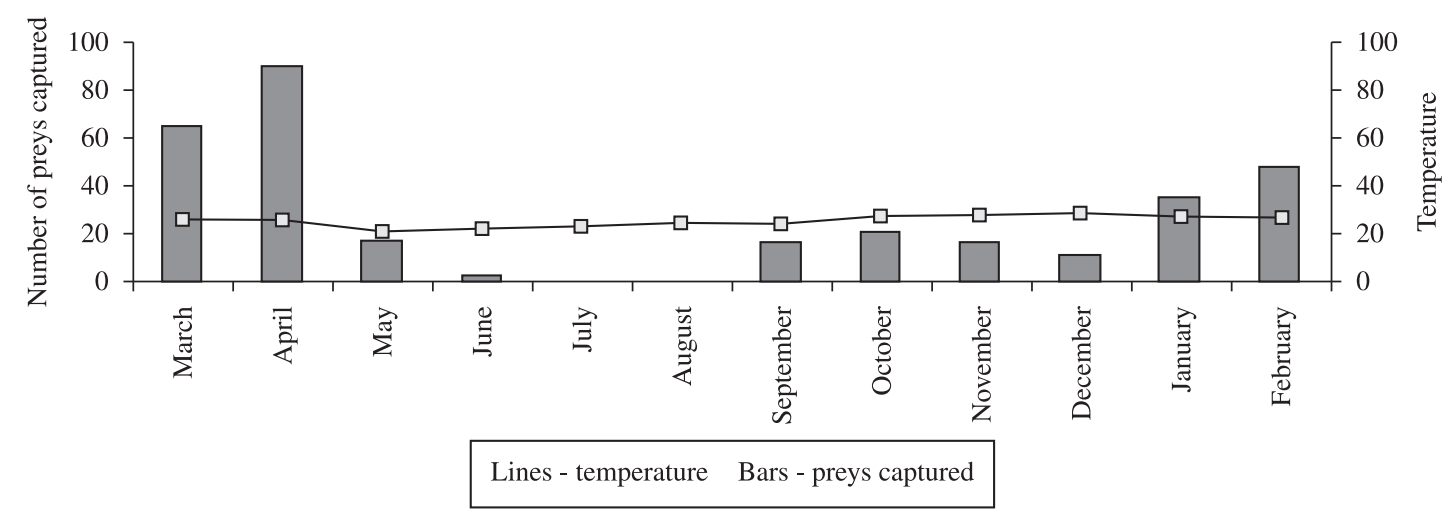

Figure 3. Snail Kite predation rates during the wet and dry season and related to temperature from March/08 to February/09 in the Lagoa Maior, Três Lagoas, MS.

Table 1. Consumption of prey by Snail Kites in four foraging sites (quadrants) during the wet (no parentheses) and dry (in parentheses) seasons in the Lagoa Maior, Três Lagoas/MS.

\begin{tabular}{lcccc}
\hline \multirow{2}{*}{ Period } & \multicolumn{4}{c}{ Number of captures } \\
\cline { 2 - 5 } & Quadrant I & Quadrant II & Quadrant III & Quadrant IV \\
\hline Morning & $3(1)$ & $16(18)$ & $33(10)$ & $88(21)$ \\
Evening & $15(3)$ & $10(5)$ & $21(12)$ & $20(13)$ \\
Total & $18(4)$ & $26(23)$ & $54(22)$ & $108(34)$ \\
\hline
\end{tabular}

of territory between males was also observed. During the flight, capturing prey or even the landing in the area, the dominant male, detected by the narrow white bar on its wings, caused temporary dispersion to the other one from areas III and IV.

\section{Discussion}

\subsection{The influence of rainfall fluctuations on prey availability and hunting strategies}

We noticed a predominant consumption of the snail of the genus Pomacea sp, but we also recorded rare crab consumption. Bourne (1993) stated that "kites also appeared capable of tracking temporal profitability changes" and Sykes and Kale II (1974) and Mader (1981) only mentioned that some different food resources perhaps can be changed during the dry and wet seasons. Davis et al. (1994) pointed out the Snail Kites turned to this alternative only when apple snails become scarce. However, there were few crabs captured during this study to infer it is an alternative prey to Snail Kites. Mader (1981) found different proportions in Venezuela during the wet season, with the predominance of crabs (68\%) over Pomacea (32\%). Perhaps this difference can be reflected in different population fluctuations between the habitats studied instead of Snail Kite preferences.

This higher abundance of apple snails theoretically depends on the following facts: individual density, water depth, temperature, oxygen concentration and also vegetation density (Beissinger, 1983). In fact, as seen in Figure 2, the highest capture rates of Pomacea sp. was observed in April, when rainfall periods declined and provided a larger area of water surroundings. This also provides more vegetation for Pomacea foraging, which may explain their higher abundance in this period. According to Donnay and Beissinger (1993), the Pomacea spread and become more active, when they feed on water-based riparian plants. Moreover, the higher predation rate in this period can be also influenced by another reason: the reproductive period of this mollusk in the beginning of the dry season (Estela and Naranjo, 2005).

The amount of prey capture between the different seasons varied dramatically (Table 1 and Figures 2 and 3 ). In the wet season, the food supply was increased, as indirectly evidenced by the higher amount of prey captured. However, the temperature and predation rates showed a slight tendency to positive correlation. Actually, temperature is not the main factor to determine seasonal periods in the Neotropical wetlands. In fact, the climate in this habitat is notably seasonal because of the rainy summers and dry winters. Concerning the Snail Kite habitats, these rainfall fluctuations cause flood pulses in one year in Brazilian wetlands (Junk and Silva, 1999).

The Pearson coefficient concerning the rainfall and predation also indicated a tendency to positive correlation between these parameters. In this way, the decrease in rainfall levels probably causes the increase the abundance of apple snails and perhaps makes them more vulnerable to avian predation (Estela and Naranjo, 2005). These factors lead us to suppose that at the end of the wet season there are a higher number of Pomacea, causing a higher rate of predation. However, the causes of fluctuations in snail 
abundance are still not completely understood (Estela and Naranjo, 2005). There are probably multiple processes, as mentioned above. More research is needed on the biology of these gastropods, especially in the Cerrado biome where our study was conducted.

Moreover, the high level of predation observed in the wet season can be caused by another factor: the breeding period of Snail Kites during this season. So, it is expected higher consumption of prey from December to February (Figures 2 and 3) when they demand more energy for reproduction (Sick, 2001). We observed males showing reproductive displays in January 2009 by flying over the bushes on flocks in the island (quadrant IV).

In the dry season the Snail Kites spent more time in flight and landing, including moving out of the study area (Figure 1). Although the foraging is predominant during the highest food abundance at the end of the wet season (Figures 2 and 3), it shows a similar period of exploratory flights in relation to the dry season (Figure 1). According to Bell (1991) some animals exhibit exploratory movements during times of high food resources in order to learn the location of food or other resources during periods when these items are few available.

According to Bennets and Kitchens (2000), during extreme low-water events (dry seasons), snails become temporarily unavailable to predation. In this study, the predation rate declined during the dry season, and also an increase in the occurrence of prolonged Snail Kite landing is observed (Figure 1). The explanatory flight numbers remain quite similar to the wet season. However much foraging invested in the water became unsuccessful because the shells were empty and they were quickly discarded. As a result, the frequency of foraging decreased gradually (Figures 2 and 3).

In summary, the long periods of perching during the dry season may be related to a need to search and locate prey before investing their energy in foraging. It can explain the use of the "Still-Hunting" foraging strategy during the wet season and the "Course-Hunting" strategy (Figure 1) adopted due to lack of food in the dry season, as observed in Beissinger (1983). However, this hypothesis is based on a single year of sampling (temporality). In fact, further studies covering at least two years of sampling (seasonality) are needed to confirm or to refute this hypothesis.

Snyder and Snyder (1969) report that the composition of the vegetation type influences the foraging strategy of kites, but did not find that the seasonality may also influence the choices of these strategies. According to Tanaka et al. (2006) the main determinants of foraging strategy and success of these predators should be directly related to the availability of perches, or indirectly through the different densities of the food supply. In this study we confirm this hypothesis, but we could provide further information related to time and space. The main factor for the use of these different strategies is probably related to the food availability during the wet and dry periods (time) as observed in Table 1 and Figure 1. However, the availability of perches should be considered (space).
Although the amount of places to perch is abundant and equally distributed among the other quadrants considered, the quadrant IV features an island with abundant area for landing and protection. Table 1 shows that about 50\% of predation (142 from 289 captures) occurred in this foraging location.

In contrast, they seem not to be so affected by temporality when daily activities are concerned. In both seasons the Snail Kites tend to inactivity in the afternoon. In the 289 successful catches, only $102(36 \%)$ occurred in the afternoon (Table 1). Beissinger (1983) also observed both the decline in foraging activity and the increase in landings during the evenings. The author attributes the fact to the difficulty by Snail Kites for visual detection of prey with a gradual decrease in brightness during the day, when snail densities are under the highest diurnal illumination and temperatures are relatively low. Therefore, kites respond only to increasing temperature and illumination during the morning and decreasing values for these parameters during the early evening. Another possible cause is satiation (Beissinger, 1983).

\subsection{Temporal prey availability and its influence on territoriality and nomadic tendencies}

Even if a rare behaviour, Haverschmidt (1970) mentions the occurrence of interspecific aggression by the Snail Kite. Beissinger (1983) found this behaviour in only $0.1 \%$ of Snail Kite interactions. In our observations, interspecific aggression was not observed, and often the same tree was perched by Snail Kites, cormorants (Phalacrocorax brasilianus) and herons (Egretta tula), without any antagonistic occurrence detected. Most likely the nutritional preferences among them could justify the lack of aggressiveness, as noted by Haverschmidt (1970). In the studied area, the only hypothetic foraging competitor to the Snail Kite would be the limpkin (Aramus guarauna) that also feeds on snails and crabs, however no aggressiveness were detected between these species.

Conversely, aggressiveness among individuals of Snail-kite was recorded in this study. According to Stillman et al. (1996, 1997) and Triplet et al. (1999) conspecific aggressiveness can influence both foraging rates and size preferences of consumers.

Bourne (1985) and Tanaka et al. (2006) show higher densities of foraging in kites found at sites with higher availability of perches, but approaches about dominance sites were not focused on in these studies. Magalhães (1990) found two Snail Kites perching points close to small bodies of water. According to this author, generally they tend to use both the landing and feeding observations (often on poles, trees and reeds on the shore of the water area), with no overlap between landings of individual occupation. This was observed here, since each individual uses the same landing for observation and manipulation of prey, suggesting a clear distribution of territories, except in low food conditions, as follows.

Some models predict that generally interactions with competitors are costly and smaller prey should be favored to 
minimise handling times (Nilsson et al., 2000). According to Bourne (1985), diet differences between adults and juveniles were associated with differences in handling times. Adults took significantly larger apple snails than did juveniles and spent significantly less time handling these snails. This suggests a kind of non-niche overlap when the habitat provides enough prey for both. This assumption is in agreement with our observations on the variations of prey availability during the temporality and landing sites. We observed that food availability decreased during the dry season (Table 1 and Figures 2 and 3), as attempts to capture were frustrated (empty shells). As a result, the Snail Kite males enlarged their foraging area, leaving quadrants III and IV and spreading to the other quadrants. So, they did not allow the female and young into quadrants I and II during the dry season, due to increased competition for food.

Despite this attention on the consequences of dispersal, relatively little work has been done on the factors influencing whether an animal stays or leaves a given site (Bennetts and Kitchens, 2000). In this case, the advantages of leaving may outweigh the advantages of staying for females and young Snail Kites. In this seasonal extremity (drying event), food becomes virtually unavailable, such as observed for June, July and August (Figures 2 and 3). At such low resource levels, the decision of whether to stay or leave a given site is undoubtedly influenced by proximate factors: a given bird either leaves or it starves, mainly if it is not a dominant. Bennetts and Kitchens (1997a) also report this behaviour for juvenile Snail Kites. This response is also consistent with the previous reports by Beissinger and Takekawa (1983) and Takekawa and Beissinger (1989) during such events.

Takekawa and Beissinger (1989) suggested that during dry periods and corresponding low food availability, Snail Kites exhibited "massive dispersal" to refugia habitats. Our observations are partially in contrast to this view, indicating that at least the males can stay, even during times of low food abundance. However, we do not believe that our data are in conflict with the suggestion of these authors mentioned above. Rather, we believe that the disparity of our results and interpretations reflect the different resource levels (food availability) during the respective studies. However, all these aspects show intraspecific intolerance in Snail Kites anyway, with male dominance in relation to habitat exploited. Tanaka et al. (2006) also found competitive interactions of foraging in the Snail Kites, mainly in areas with high individual density.

In synthesis, our results on Snail Kite movements confirm the following hypotheses: a) Snail Kite males may expand their foraging sites when site profitability falls below a certain level; b) female and immature Snail Kites exhibit nomadic tendencies (Sykes Junior, 1983; Bennetts, 1993; Bennetts and Kitchens, 1997a, b) in response to sporadic food conditions. This is specially pointed out if they depend on few species of prey, as is observed for Snail kites and other birds (Galushin, 1974; Andersson, 1980; Sonerud et al., 1988; Frederick et al., 1996).
According to Wiens (1994), as the distribution of resources becomes more patchily distributed and less predictable in space and time, nomadic tendencies may emerge. At the other extreme, when resources are predictable and evenly distributed in time and space, site tenacity may be favoured (Alerstam and Enckell, 1979). Actually, there may even be advantages for territoriality, provided that the expense of resource defense is not excessive (Wiens, 1994). We observed Snail kites using smaller areas for several months during periods of localised, extremely high food availability, as evidenced by many captures (Table 1) and food abundance (Figure 1). Snyder and Snyder (1969) reported similar territory defense of small areas with superabundant food.

Acknowledgements - Thanks to José Ragusa-Neto and to the anonymous reviewers for the suggestions and revision of this study and also to Mr. Kevin Mundy for the English version.

\section{References}

ALERSTAM, T. and ENCKELL, PH., 1979. Unpredictable habitats and evolution of bird migration. Oikos, vol. 33, p. 228-232. http:// dx.doi.org/10.2307/3543999

ALVES, MAS. and PEREIRA, EF., 1998. Richness, abundance and seasonality of bird species in a lagoon of an urban area (Lagoa Rodrigo de Freitas) of Rio de Janeiro, Brazil. Revista Brasileira de Ornitologia, vol. 6, p. 110-116.

ANDERSSON, M., 1980. Nomadism and site tenacity as alternative reproductive tactics in birds. Journal of Animal Ecology, vol. 49, p. 175-184. http://dx.doi.org/10.2307/4282

BELL, WJ., 1991. Searching behaviour: the behavioural ecology of finding resources. London: Chapman and Hall.

BENNETTS, RE., 1993. The Snail Kite: a wanderer and its habitat. Florida National, vol. 66, p. 12-15.

BENNETTS, RE. and KITCHENS, WM., 1997a. The demography and movements of Snail Kites in Florida. Gainesville: U.S. Geological Survey, Biological Resources Div., Florida Cooperative Fish \& Wildlife Research Unit. Tech. Rep. 56.

-, 1997b. Population dynamics and conservation of Snail Kites in Florida: the importance of spatial and temporal scale. Colon Waterbirds, vol. 20, p. 324-329. http://dx.doi.org/10.2307/1521700

-, 2000. Factors influencing movement probabilities of a nomadic food specialist: proximate foraging benefits or ultimate gains from exploration? Oikos, vol. 91, no. 3, p. 459-467. http://dx.doi. org/10.1034/j.1600-0706.2000.910306.x

BEISSINGER, SR., 1983. Hunting behavior, prey selection, and energetic of Snail Kites in Guyana. Auk, vol. 100, p. 84-92.

BEISSINGER, SR. and TAKEKAWA, JE., 1983. Habitat use by and dispersal of Snail Kites in Florida during drought conditions. Florida Field Naturalist, vol. 11, p. 89-106.

BIBBY, C., JONES, M. and MARSDEN, S. 2000. Expedition field techniques: bird surveys. Cambridge: BirdLife International.

BOURNE, GR., 1985. The role of profitability in Snail Kite foraging. Journal of Animal Ecology, vol. 54, p. 697-709. http:// dx.doi.org/10.2307/4372 
-, 1993. Differential snail-size predation by snail kites and limpkins. Oikos, vol. 68, p. 217-223. http://dx.doi.org/10.2307/3544833

COLLET, SF., 1977. Sizes of snails eaten by Snail Kite and Limpkin in a Costa Rica marsh. Auk, vol. 94, p. 365-367.

DAVIS, SM., JOHN, C. and OGDEN, J., 1994. Everglades: The Ecosystem and its Restoration. CRC Press.

DÍAZ, JM. and BLANCO, JF., 1996. Notas comparativas sobre el forrajeo ejercido por el Águila Caracolera (Rostrhamus sociabilis) y la Viudita Alegre (Aramus guarauna) sobre moluscos de agua dulce, en la laguna de Sonso, Valle del Cauca. Cespedesia, vol. 21 , no. 68 , p. 171-174.

DONNAY, TJ. and BEISSINGER, SR., 1993. Apple Snail (Pomacea doliodes) and Freshwater Crab (Dilocarcinus dentatus) population fluctuations in the Llanos of Venezuela. Biotropica, vol. 25, no. 2, p. 206-14. http://dx.doi.org/10.2307/2389184

ESTELA, FA. and NARANJO, LG. 2005. Segregación en el tamaño de caracoles depredados por el Gavilán Caracolero (Rostrhamus sociabilis) e el Carrao (Aramus guarauna) en el suroccidente de Colombia. Ornitología Colombiana, vol. 3, p. 36-41.

ESTEVES, FA., 1988. Fundamentos de Limnologia. Rio de Janeiro: Ed. Interciência, FINEP.

FREDERICK, PC., BILDSTEIN, KL., FLEURY, B. and OGDEN, J., 1996. Conservation of large, nomadic populations of White Ibises (Eudocimus albus) in the United States. Conservation Biology, vol. 10, p. 203-216. http://dx.doi.org/10.1046/j.15231739.1996.10010203.x

GALUSHIN, VM., 1974. Synchronous fluctuations in populations of some raptors and their prey. Ibis, vol. 116, p. 127-134.

HAVERSCHMIDT, F., 1970. Notes on the Snail Kite in sumariman. Auk, vol. 91, p. 819-820.

JUNK, WJ. and DA SILVA, C., 1999. O conceito do pulso de inundação e suas implicações para o Pantanal de Mato Grosso. In Anais do II Simpósio sobre recursos naturais e sócio-econômicos do Pantanal: Manejo e Conservação, 1999. Corumbá: EmbrapaPantanal. p. 17-28.

LEIPNITZ, II., SILVA, JLL., LEIPNITZ, B., LEAO, CJ. and FERREIRA, F., 2005. Amebas testáceas em sedimentos quaternários do sistema lacustre de Três Lagoas, MS. Gaea, vol. 1, no. 2, p. 82-93.

MADER, WJ., 1981. Notes on nesting raptors in the llanos of Venezuela. Condor, vol. 83, p. 48-51. http://dx.doi. org/10.2307/1367600

MAGALHÃES, M., 1990. Hábitos alimentares e estratégia de forrageamento de Rosthramus sociabilis, no Pantanal de Mato Grosso, Brasil. Revista Brasileira de Ornitologia, vol. 1, p. 95-98.

MORENO, AB., LAGOS, AR. and ALVES, MAS., 2004. Water depth selection during foraging and efficiency in prey capture by the egrets Casmerodius albus and Egretta thula (Aves, Ardeidae) in an urban lagoon in Rio de Janeiro State, Brazil. Iheringia, vol. 95, no. 1 , p. 107-109

NILSSON, PA., NILSSON, K. and NYSTRÖM, P., 2000. Does risk of intraspecific interactions induce shifts in aquatic predators? Behavioral Ecology and Sociobiology, vol. 48, p. 268-275. http:// dx.doi.org/10.1007/s002650000235
PIMENTA, FE., DRUMMOND, JCP. and LIMA, AC., 2007. Aves aquáticas da Lagoa da Pampulha: seleção de hábitats e atividade diurna. Lundiana, vol. 8, no. 2, p. 89-96.

PIRATELLI, JÁ., SIQUEIRA, MAC. and MARCONDESMACHADO, LO., 2000. Reprodução e muda de penas em aves de sub-bosque na região leste de Mato Grosso do Sul. Revista Brasileira de Ornitologia, vol. 8, no. 2, p. 99-107.

SICK, H., 1997. Ornitologia Brasileira. 2nd ed. Brasília: Ed. Universidade de Brasília.

SILVA, DS. and BLAMIRES, D., 2007. Avifauna urbana no Lago Pôr do Sol, Iporá, Goiás, Brasil. Lundiana, vol. 8, no. 1, p. 17-26

SONERUD, GA., SOLHEIM, R. and PRESTRUD, K., 1988. Dispersal of Tengmalm's Owl Aegolius funereus in relation to prey availability and nesting success. Ornis Scandinavica, vol. 19, p. 175-181. http://dx.doi.org/10.2307/3676555

SNYDER, NFR. and SNYDER, HA., 1969. A comparative study of mollusk predation by Limpkins, Everglade Kites, and Boattailed Grackles. Living Bird, vol. 8, p. 177-223.

SNYDER, NFR. and KALE II, HW., 1983. Mollusk predation by Snail Kite in Colombia. Auk, vol. 100, p. 93-97.

STILLMAN, RA., GOSS-CUSTARD, JD., CLARKE, RT. and DURELL, SEA., 1996. Shape of the interference function in a foraging vertebrate. Journal of Animal Ecology, vol. 65, p. 813824. http://dx.doi.org/10.2307/5679

STILLMAN, RA., GOSS-CUSTARD, JD. and CALDOW, RWG., 1997. Modelling interference from basic foraging behaviour. Journal of Animal Ecology, vol. 66, p. 692-703. http://dx.doi. org/10.2307/5922

SYKES, P. and KALE II, HW., 1974. Everglade kite feed on non-snail prey. Auk, vol. 87, p. 580-584.

SYKES JUNIOR, PW., 1983. Recent population trends of the Snail Kite in Florida and its relationship to water levels. Journal of Field Ornithology, vol. 54, p. 237-246.

TAKEKAWA, JE. and BEISSINGER, SR., 1989. Dispersal, cyclic drought, and the conservation of the Snail Kite in Florida: lessons in critical habitat. Conservation Biology, vol. 3, p. 302-311. http:// dx.doi.org/10.1111/j.1523-1739.1989.tb00090.x

TANAKA, MO., SOUZA, ALT. and MÓDENA, ES., 2006. Habitat structure effects on size selection of Snail Kites (Rosthramus sociabilis) and limpkins (Aramus guarauna) when feeding on apple snails (Pomacea spp). Acta Oecologica, vol. 30, p. 88-96. http://dx.doi.org/10.1016/j.actao.2006.02.003

TRIPLET, P., STILLMAN, RA. and GOSS-CUSTARD, JD., 1999. Prey abundance and the strength of interference in a foraging shorebird. Journal of Animal Ecology, vol. 68, p. 254-265. http:// dx.doi.org/10.1046/j.1365-2656.1999.00280.x

TYRRELL, M. and HORNBACH, DJ., 1998. Selective predation by muskrats on freshwater mussels in two Minnesota rivers. Journal of The North American Benthological Society, vol. 17, p. 301-310. http://dx.doi.org/10.2307/1468333

WIENS, JA., 1994. The Ecology of Bird Communities: Processes and Variations. Cambridge: Cambridge University Press. 
